greatly to the difficulties already spoken of. Even when an animal of one form is gravely suspected to be merely the immature stage or corresponding sex of another form it is most difficult to prove it, and it frequently requires a whole series of researches conducted by practised biologists with logical exactitude to show that such is really the case.

Under these circumstances, even with the now rich collections and well-stored library of the Zoological Station, it was a serious question how the proposed "History of the Life of the Bay of Naples" could be best accomplished. Dr. Dohrn has wisely adopted the project of attacking the fortress by a number of small approaches. By dividing the labour in to a large series of restricted monographs he hopes finally to accomplish a complete account of the fauna and flora of the Bay of Naples. In the first place, under this system each of his assistants can thus take up the group he is most familiar with, and work it out. Then in this way he is likewise able to secure the contributions of various naturalists who pay temporary visits to the Zoological Station, but who would not bind themselves to join in an extensive general work on the whole subject.

It will be seen by reference to our advertising columns that Dr. Dohrn's scheme thus elaborated is now on the eve of execution. Two of the proposed monographic memoirs on the Ctenophoræe by Dr. Cheen of Leipsic, and on the Fishes of the genus Fierasfer, by Prof. Emery of Cagliari, are already issued, and three other memoirs are announced as being in preparation for the present year. Dr. Dohrn is quite cosmopolitan in his arrangements. Though, as might have been expected, the greater number of his fellow-workers are natives of the Fatherland, he has many Italian co-operators, and the monographs may be written in German, Italian, English, or French. It is with some regret we observe that no English naturalist is yet on the list of contributors, although, as is well known, many of our country. men have done good work on Dr. Dohrn's "tables." We trust that English recruits may still be enlisted in so good a cause, and that the "Fauna and Flora of the Bay of Naples" may attain to a goodly list of subscribers, and be brought to a satisfactory conclusion.

\section{CHARLES FREDERIC KUHLMANN}

W

$E$ regret to record the death, at Lille, during the past week, of Charles F. Kuhlmann, the distinguished French chemist and economist. Born at Colmar, May 22,1803 , he pursued his scientific studies under Vauguelin at Strassburg, and later at Paris. In 1832 he was appointed Professor of Applied Chemistry at Lille. Soon after he devoted himself almost exclusively to the practical solution of the problems of manufacturing chemistry, and established at Lille extensive works, which rank today among the important chemical manufactories of the world. During the past forty years he has been a prominent figure in the industrial, scientific, and even political circles of France, attracting general admiration by a remarkable combination of inventive power and executive ability. The Government named him Commander of the Légion d'Honneur, and the French Academy of Sciences elected him a corresponding member, in recognition of his important services, while he was frequently called upon to occupy prominent posts of responsibility in public life and commercial undertakings. His failing health during the past year forced him to decline one of the leading honours in the scientific world of France, the presidency of the Société Française pour l'Avancement des Sciences.

As an investigator Kuhlmann was a prominent member of that group of Alsatian chemists which includes Wurtz, Friedel, and Schuitzenberger, and forms the chief school of modern French chemistry. His researches, extending over nearly every department of inorganic chemistry, and touching on the tinctorial branches of organic chemistry, are characterised by a broad range of knowledge, a happy application of fact and theory, and a marked reverence for the demands of pure chemistry, while contributing so notably to the advancement of applied science.

First among his great researches mention should be made of that on baryta compounds, made over twenty years since, and by means of which he created the entire industry of this important group of salts. Another investigation, scarcely less valuable, was that made a few years previously, which led to the introduction of the process of saturation in the manufacture of sugar. Equally prolific of practical results were his extensive studies on the crystallisation of insoluble bodies, on the chemistry of mortars and cements, of manures, of bleaching, of dyeing and printing, and of numerous other branches. Especially interesting were his researches (1847) on the formation of nitric acid from ammonia, and on the relation of this reaction to the fertility of the soil. Among his more purely scientific investigations mention should be made of those on the formation of ethers, on the formation of cyanides and of prussic acid, on nitrous oxide, on the use of oxide of iron as an oxidising agent for organic compounds, on the action of gases on minerals, on the use of gaseous hydrofluoric acid for the analysis of silicates, and on a variety of minerals. The subject of crystallisation was throughout his career of investigation one of Kublmann's favourites, and we are indebted to him for the artificial reproduction of a variety of natural minerals, the most novel of which are the pseudomorphic forms of protoxide of manganese, of the sulphides of copper and lead, and of these metals themselves.

In 1879 Kuhlmann gathered together his numerous researches, extending over a period of forty years, into a volume of 750 pages, in which we have a remarkable picture of his many-sided and untiring activity.

The deceased leaves behind him a son who has already obtained a name as a chemist, and who made an able report to the French Government on the Chemical Section of the Philadelphia Exhibition.

T. H. N.

\section{THE SCIENTIFIC SOCIETIES OF DUBLIN}

$\mathrm{F}$ the scientific societies of Dublin two take special rank as publishing societies; but from inquiries made of us we conclude that their publications are not everywhere known.

The Royal Irish Academy issues both Transactions of a quarto size and Proceedings in octavo. Of its series of Transactions 26 volumes have been published. Of these vols. I to 23 contained memoirs chiefly on Science, but occasionally on Polite Literature and Antiquities. Vol. 24 was divided into two sections - the first, Science; the second, Polite Literature and Antiquities. Vols. 25 and 26 were exclusively Science. Vol. 27, in course of publication, is devoted to Polite Literature and Antiquities; and vol. 28 , which also is in course of publication, is devoted to Science. These quarto volumes contain from 600 to 700 pages each, with numerous plates and other illustrations. To give some idea of their contents we add the following analysis of vol. 26. It contains papers on Astronomical Subjects by Dr. Doberck (2), J. Birmingham, J. L. E. Drever, and C. E. Burton; on Meteorological Subjects, by Dr. H. Lloyd; on Geological Subjects, by Rev. Dr. S. Haughton, Dr. E. Hull, Dr. A. Leith Adams, and Prof. O'Reilly (2); on Mathematical Subjects, by J. C. Malet (3), Dr. A. S. Hart, Dr. J. Casey; on Biological Subjects, by Dr. R. J. Harvey, Dr. E. P. Wright (4), and W. H. Mackintosh; on Chemical Subjects, by H. N. Draper and R. J. Moss. The memoirs which form the volumes of Transactions are published shortly after they are read, and without waiting to form a part of a volume. The Proceedings, like the Transac- 
tions, now also form two series: the Science Parts being published twice a year, in December and April, and the Polite Literature and Antiquary Part once a year, in December. Quite recently the Academy have determined to publish another series of quarto Transactions under the title of "The Cunningham Memoirs," part I of the first volume of which, containing a memoir by Dr. John Casey, F.R.S., on Cubic Transformations, has just appeared.

The publications of the Royal Dublin Society are of the same type as those of the Irish Academy, except that they are exclusively confined to science. Of their new series of Transactions, parts I to 13 of volume $I$ have been published, and for convenience of publication the first two parts of volume 2, containing "Observations of Nebulæ and Star Clusters, I848-1878," by the Earl of Rosse, have also appeared. The first two volumes of these Proceedings have been published, and a part makes its appearance pretty regularly every third month. Following the example of the Academy, the memoirs forming the Transactions are published separately.

It would thus appear that not only is there evidence of scientific life among the societies of Dublin, but that there is also an abundant opportunity for the publication of any really valuable scientific information, and so far at least as the publications of the Irish Academy are concerned they fall in no respect as regards type, paper, or illustrations, behind the best of our London societies.

\section{JOHN DUNCAN}

A LONG with a cheque for $5 l$. to John Duncan, whose story was told by Mr. W. Jolly in NATURE of January 20 , we have received the following note from Mr. W. Westgarth :-

January 27, $188 \mathbf{1}$

DEAR SIR, - On reading the account of John Duncan in your last week's issue, it occurred to me that surely your readers would respond to your invitation to get up a small fund, say of $10 \%$. to $200 l$., for the brave old man who has so long and perseveringly fought, and against all "odds," for the cause of science and mind. I enclose $5 l$. towards the object. Should you see objections to opening a list in NATURE, please send on my small dole to Mr. Jolly as he directs.

W. WESTGARTH

We have the greatest pleasure in acting upon $\mathrm{Mr}$. Westgarth's hint, and we trust that many of our readers will be prompt to follow his good example. Subscriptions addressed to the Editor of NATURE, 30, Bedford Street, Covent Garden, W.C., will be duly forwarded. We have already received the following :-

$\begin{array}{lllllllllll}\text { W. Westgarth } & \ldots & \ldots & \ldots & \ldots & \ldots & 5 & 0 & 0 \\ \text { Publishers of NATURE } & \ldots & \ldots & \ldots & \ldots & 5 & 5 & 0 \\ \text { F.R.S. } \ldots & \ldots & \ldots & \ldots & \ldots & \ldots & \ldots & 0 & 10 & 0 \\ \text { Mrs. Forster } & \ldots & \ldots & \ldots & \ldots & \ldots & \ldots & \text { I } & 0 & 0\end{array}$

\section{CASSELL'S NATURAL HISTORY ${ }^{1}$}

$\mathrm{T}^{\mathrm{H}}$

$\mathrm{E}$ third volume of this useful cyclopædia of zoology consists of the concluding portion of the Birds by R. Bowdler Sharpe, and of the Reptiles and Amphibia by the Editor. On glancing over the well-printed and beautifully-illustrated pages, a few facts have struck us, to which, for the benefit of the series, we would call the editor's attention. In the opening sentence of Chapter I. of this volume we are referred to "the preceding chapters" for an account of the Picarian birds. The context proves it should be to the preceding volume. This, which might mislead the reader, is evidently the result of the publication of the work in parts, and could be easily avoided.

All through Mr. Sharpe's portion of the work, when the scientific names of birds are referred to they are

I "Cassell's Natural History." Edited by Prof. P. Martin Duncan, M.B., F.R.S. Vol. III. (London, Paris, and New York: Cassell, Petter, Galpin, and Co., 1880.) quoted generally within brackets in the same line as the popular name; while in the editor's special portion no such useful uniformity is attended to. Sometimes, as on p. 245 , the eye has to wander from the text to foot-notes at the bottom of the page; sometimes, as at p. 248 , the name is quoted after Mr. Sharpe's fashion (for a mixture of both styles see p. 362). The use of the word "kind," when the editor refers to "species," is in our judgment, though perhaps sanctioned by its use in the English translation of the Bible, not happy. Thus we read that, while genera among the reptiles are abundant, "kinds" are numerous. The "kinds" of some families swim freely; some "kinds" have a skin; by the way, what kind of a reptile be it that has no skin? In other cases the word "member" instead of species is used. Is it not a mistake to say that in many Chelonians "the wellknown 'tortoise-shell' covers over all the hind parts." Surely in Caretta squamosa the tortoise-shell plates cover over most of the carapace. While the families of the Chelonian order are given, we find, when we come to the Lacertine order, no intelligible mention of the families of the split-tongued lizards. In referring to the important paper on Archæopteryx by the Professor of Geneva, the editor ought to have seen that the name of Carl Vogt was correctly spelled. The divisions of the Snakes is such as must necessarily confuse any student. The suborder Thanatophidia is made to include two sub-orders in the text, when in the table of classification one of these sub-orders, Solenoglypha, is called a family. The groove-fanged Opisthoglypha are included with the Aglyphodontia with solid teeth. In a work of this nature nothing is, we take it, of more importance than that there should be some well-defined system of classification, not necessarily to be treated of in full detail, but as far as is possible to be rigidly adhered to. That this is possible, a glance over the sections of this and the previous volume treating of Birds will abundantly demonstrate; and that this is practicable, even with an extreme compression of space, is also to be proved by an appeal to the way in which the eighth order of Birds is managed, where, though only three pages were allowed to this most interesting and important of orders, yet we are even in these few lines enabled to get an idea of the orderly sequence of its families. This work is in many ways so excellent, that we venture on these criticisms with the object of trying to keep it up to a fairly good standard, and of making it useful in some measure as a work of reference.

As specimens of the excellent illustrations in this volume we have, through the courtesy of the publishers, the opportunity of presenting to our readers the two following. The Common Quail (Coturnix dactylisonans) visits Europe in the summer, when prodigious numbers are trapped and sold for purposes of food. Waterton mentions that 17,000 specimens were brought to Rome in one day. They are to be found in large quantities on the coasts of the Mediterranean, and so abundant are they in the beautiful Island of Capri, that it is said that it was from this source that the bishops in the olden times derived a large part of their wealth. The Quail is most rapid in its flight, and performs long and fatiguing journeys. Sunset is its time for active exertion; during the day it remains quite quiet, reserving its energies for the evening, when it goes off in quest of food.

Their favourite nourishment is insects, but at times they feed on grain and seeds; small stones are also swallowed to facilitate digestion. The habits of the quail are most unamiable and unsocial, and generally, when they meet with one of their own species, they display a very pugnacious disposition. The female has a much better nature; she is a most excellent mother, even protecting young birds who have been deprived of their parents' care. She builds her nest of small portions of plants, and lays eight to fourteen eggs; these are pear- 